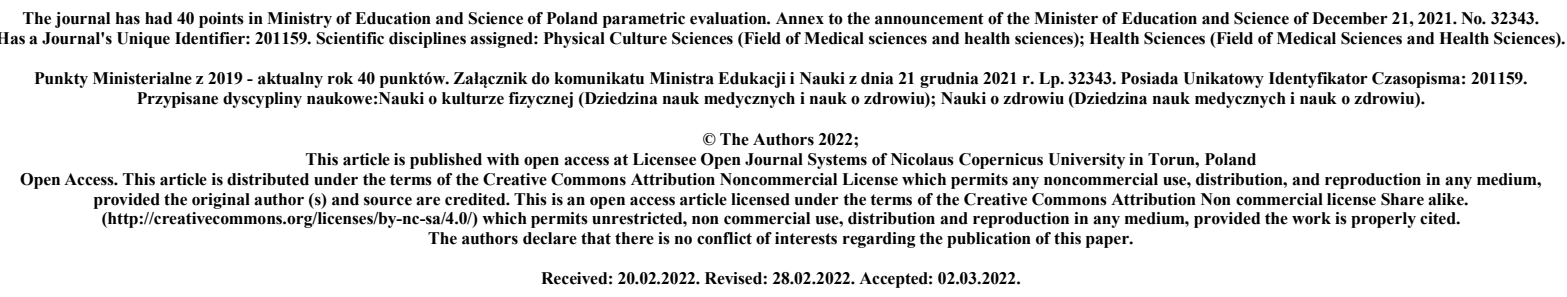

\title{
Udar przysadki jako rzadka przyczyna hipoglikemii - opis przypadku
} Pituitary apoplexy as a rare cause of hypoglycemia - a case report

\author{
Justyna Cabaj ${ }^{1}$, Julia Bargiel ${ }^{1}$, Marcin Lewicki ${ }^{2}$
}

1. Studenckie Koło Naukowe przy Katedrze i Klinice Endokrynologii UM w Lublinie

2. Katedra i Zakład Epidemiologii I Metodologii Badań Klinicznych UM w Lublinie

\begin{abstract}
Introduction: Pituitary stroke is a relatively rare emergency in endocrine practice. In majority of patients, deficiencies of at least one hormone secretion are observed, and clinical manifestations in the form of hypotension and hypoglycemia results from insufficient secretion of adrenocorticotropic hormone. The aim of the study is to present a case report of a patient with symptoms of hypotension and hypoglycemia resulting from a pituitary stroke.

Case report: A 72-year-old patient with type 2 diabetes, was admitted to the Department of Endocrinology due to severe hypoglycemia and hypotension accompanied by urinary retention. He was initially diagnosed with sulfonylurea-related hypoglycemia. In the physical examination, attention was drawn to the drooping of the left eyelid, suggesting nerve III palsy. An urgent CT examination was performed, which showed no signs of intracranial bleeding, but the blurred outline of the pituitary gland was visualized. Due to the clinical picture, a pituitary stroke was suspected, and an immediate evaluation of the pituitary function was ordered. The results showed decreased levels of ACTH, cortisol, TSH, FT4 and FT3 and patient was diagnosed with hypopituitarism. The MRI imaging showed recent hemorrhagic changes in the pituitary gland, most likely due to macroadenoma.

Conclusion: If a pituitary gland stroke is suspected, MRI and laboratory tests, including assessment of hormonal function, should be performed. Treatment consists mainly of hormone replacement, and in some cases surgical treatment. The differential diagnosis mainly includes subarachnoid bleeding and meningitis.
\end{abstract}

Key words: Pituitary apoplexy, hypoglycemia, case report

\section{STRESZCZENIE}

Wprowadzenie: Udar przysadki jest stosunkowo rzadko spotykanym stanem nagłym w praktyce endokrynologicznej. Może być spowodowany ostrym krwotokiem i/lub niedokrwieniem przysadki, na ogół w obrębie niezdiagnozowanego gruczolaka. U 
przeważającej części chorych obserwuje się niedobory minimum jednego hormonu, gdzie najczęściej pierwsze manifestacje $\mathrm{w}$ postaci hipotonii i hipoglikemii wynikają $\mathrm{z}$ niedostatecznego wydzielania hormonu adrenokortykotropowego.

Opis przypadku: 72-letni pacjent z cukrzycą t. 2 został przyjęty do Oddziału Endokrynologii w trybie nagłym z powodu ciężkiej hipoglikemii i hipotensji z towarzyszącym zastojem moczu. Wstępnie rozpoznano hipoglikemię związaną ze stosowaniem pochodnej sulfonylomocznika. Wykonane badania obrazowe uwidoczniły znacznej wielkości złóg w lewym moczowodzie, który po ustabilizowaniu poziomu glikemii usunięto. W okresie pozabiegowym w badaniu fizykalnym uwagę zwróciło opadnięcie powieki oka lewego, sugerujące porażenie nerwu III. Pilnie wykonano badanie tomografii, w którym nie stwierdzono cech krwawienia śródczaszkowego, uwidoczniono natomiast zatarty obrys przysadki. Ze względu na obraz kliniczny wysunięto podejrzenie udaru przysadki, zlecono natychmiastową ocenę osi adrenokortykotropowej i tyreotropowej. W wynikach obserwowano obniżone stężenie ACTH, kortyzolu, TSH, FT4 i FT3 i rozpoznano niedoczynność przysadki. Celem potwierdzenia rozpoznania zlecono wykonanie badania rezonansu magnetycznego, które jednak zostało przesunięte w czasie w związku z infekcją chorego wirusem SARS-Cov2. W rezonansie wykonanym po ustąpieniu zakaźności opisano świeże zmianami pokrwotocznymi w obrębie przysadki, najprawdopodobniej na tle makrogruczolaka.

Wnioski: W przypadku podejrzenia udaru przysadki należy wykonać badanie MR oraz badania laboratoryjne, w tym ocenę funkcji hormonalnej. Leczenie obejmuje głównie substytucję hormonalną, a w przypadku braku odpowiedzi leczenie zabiegowe. Diagnostyka różnicowa uwzględnia przede wszystkim krwawienie podpajęczynówkowe oraz zapalenie opon mózgowo-rdzeniowych.

Słowa kluczowe: udar przysadki, hipoglikemia, opis przypadku

\section{WPROWADZENIE}

Udar przysadki jest rzadko spotykanym schorzeniem $\mathrm{w}$ codziennej praktyce endokrynologicznej. Według badań epidemiologicznych współczynnik chorobowości wynosi około 6,2 przypadków na 100000 mieszkańców, natomiast współczynnik zapadalności - 0,17 epizodów na 100000 rocznie [1]. Udar przysadki najczęściej występuje u dorosłych w średnim wieku (50-60 lat) z przewagą u mężczyzn [2].

Kontrowersje związane $\mathrm{z}$ udarem przysadki pojawiają się już w samym ustaleniu definicji tego schorzenia. Większość autorów przyjmuje, że apopleksja przysadki obejmuje zawał krwotoczny wcześniej istniejącego guza oraz samego gruczołu [3]. Okazuje się, że udar przysadki występuje częściej u pacjentów z NFPA (non functioning pituitary adenomas), być może wynika to $\mathrm{z}$ późniejszej diagnozy i większych rozmiarów [1]. Apopleksja może wystąpić nie tylko w zmianach gruczolakowatych, ale też w takich schorzeniach jak: czaszkogardlak, torbiel rozszczepu Rathkego, gruźlica jelita, zapalenie przysadki czy ropień siodła. Udar może dotyczyć również prawidłowej przysadki w okresie okołoporodowym lub poporodowym jako następstwo wstrząsu hipowolemicznego (zespół Sheehana) [2].

Dokładna patogeneza tego schorzenia nie jest do końca poznana. Wszelkie sytuacje kliniczne, w których dochodzi do znacznego obniżenia ciśnienia mogą zmniejszyć dopływ krwi do gruczolaka przysadki i przyspieszyć udar [1]. Do czynników wyzwalających zalicza się: 1) zmniejszony przepływ krwi w przysadce lub guzie, spowodowany niedociśnieniem lub przejściowym wzrostem ciśnienia wewnątrzczaszkowego; 2) ostry wzrost przepływu krwi w obrębie guza przysadki; 3) hiperstymulacja przysadki przez estrogen lub w wyniku 
przeprowadzanych testów dynamicznych; 4) stany predysponujące do antykoagulacji takie jak choroby hematologiczne, terapia przeciwzakrzepowa czy też stosowanie leków trombolitycznych [4].

Angiografia mózgowa, ze względu na wahania ciśnienia krwi lub skurcz naczyń oraz zabiegi chirurgiczne zwłaszcza ortopedyczne i kardiologiczne, które są związane z niedociśnieniem śród- i pooperacyjnym, stosowaniem leków przeciwkrzepliwych i możliwością wystąpienia mikroemboli, mogą być czynnikiem wyzwalającym. To właśnie operacja kardiochirurgiczna jest nazywana "klasyczną" sytuacją kliniczną prowadzącą do udaru przysadki. Wynika to ze sporych wahań ciśnienia tętniczego i terapii przeciwzakrzepowej. Uraz czaszki także stanowi potencjalną przyczynę apopleksji przysadki. Jak już wspomniano wcześniej ryzykiem obarczone są również diagnostyczne testy dynamiczne $\mathrm{z}$ zastosowaniem: insuliny, TRH, GnRH, GHRH i znacznie rzadziej CRH. Mechanizmem to wyjaśniającym, wydaje się być brak równowagi pomiędzy zwiększonym zapotrzebowaniem metabolicznym wywołanym stymulacją, a zdolnością do zwiększenia przepływu krwi na poziomie gruczolaka przysadki [1].

Co więcej, naczynia gruczolaków przysadki posiadają cechy niepełnego dojrzewania oraz słabej fenestracji, a ich błony podstawne często pękają. Ta naturalna kruchość naczyń krwionośnych guza, może wyjaśniać skłonność do krwotoku [5].

Bez względu na mechanizm, krwotok oraz martwica są przyczyną wzrostu ciśnienia wewnątrzsiodłowego, co z kolei prowadzi do ucisku sąsiadujących struktur, dając określone manifestacje. Obraz kliniczny udaru przysadki jest zmienny i w dużej mierze zależy od rozległości procesu chorobowego [1].

Charakterystyczny jest nagły ból głowy, objawy podrażnienia opon mózgowo-rdzeniowych, zaburzenia widzenia, oftalmoplegia i zaburzenia świadomości [6]. Objawy te nie są swoiste i pokrywają się z objawami innych schorzeń, co wskazuje na szeroką diagnostykę różnicową, a postawienie prawidłowego rozpoznania okazać się wyzwaniem [7].

Ból głowy, który jest najczęstszą manifestacją, może wynikać z podrażnienia opon mózgowordzeniowych poprzez wynaczynioną krew i materiał martwiczy do przestrzeni podpajęczynówkowej. Jest nazywany nieraz jako "grzmot na czystym niebie" ("like a thunderclap in a clear sky"), gdyż charakteryzuje się nagłym początkiem i znacznym nasileniem [1, 8]. Zaburzenia widzenia mogą być spowodowane zajęciem nerwów wzrokowych, skrzyżowania lub dróg wzrokowych. Przejawiają się najczęściej jako niedowidzenie dwuskroniowe. Rozszerzenie źrenic i opadanie powieki są wynikiem zajęcia nerwu okoruchowego [8,9]. Z kolei zajęcie nerwu $\mathrm{V}$ może prowadzić do drętwienia twarzy. U podłoża zaburzeń świadomości leży krwotok podpajeczynówkowy, zwiększone ciśnienie wewnątrzczaszkowe, wodogłowie obturacyjne, niewydolność nadnerczy oraz ucisk podwzgórza. Kolejnym, stosunkowo częstym objawem są nudności i wymioty. Mogą być one także związane $\mathrm{z}$ podwyższonym ciśnieniem wewnątrzczaszkowym, niewydolnością nadnerczy, podrażnieniem opon mózgowych czy dysfunkcją podwzgórza [8]. Często u pacjentów $\mathrm{z}$ udarem przysadki występuje hiponatremia na skutek zespołu SIADH, wynikającego z hipokortyzolemii i niedoczynności tarczycy [10].

Z kolei SPAA (subacute pituitary adenoma apoplexy) jest definiowane przez obecność krwotoku i martwicy w obrębie guza przy braku nagłego, silnego bólu głowy, zaburzeń widzenia czy oftalmoplegii [11].

Na podstawie występujących objawów pacjenci z reguły są początkowo poddawani badaniu tomografii komputerowej (TK) w trybie pilnym. Ostry zawał krwotoczny może dawać obraz dużej, heterogennej, hipergęstej masy siodłowej z możliwym rozszerzeniem nadsiodłowym. Natomiast udar niedokrwienny lub bez wcześniejszego gruczolaka może nie dawać zmian w obrazie TK [2]. 
Niemal u 80\% pacjentów, w następstwie PA występuje niedobór przynajmniej jednego hormonu przedniego płata. Klinicznie najważniejszy wydaje się być deficyt hormonu adrenokortykotropowego (ACTH) [8].

\section{OPIS PRZYPADKU}

Pacjent lat 72 obciążony cukrzycą typu 2, otyłością, nadciśnieniem tętniczym, leczony psychiatrycznie, przewlekle leżący, został przyjęty do Oddziału Endokrynologii, w trybie nagłym z SOR, z powodu ciężkiej hipoglikemii i hipotensji.

W karetce, a następnie na Szpitalnym Oddziale Ratunkowym (SOR) oznaczono podstawowe parametry życiowe i wykonano badania laboratoryjne, w których stwierdzono hiponatremię, hipokaliemię, podwyższony poziom kreatyniny i mocznika oraz hipoglikemię (tabela 1, 2, 3, 4). Wstępnie rozpoznano hipoglikemię związaną ze stosowaniem pochodnej sulfonylomocznika. Wykonano test $\mathrm{w}$ kierunku obecności antygenu SARS-CoV-2 (wynik negatywny). Zlecono TK głowy, klatki piersiowej, jamy brzusznej i miednicy - uwidoczniono nerkę lewą z cechami znacznego zastoju i pojedynczymi złogami do $6,5 \mathrm{~mm}$, a w układzie kielichowo-miedniczkowym hyperdensyjne, lokalnie tubularne pasma niejasnej etiologii. Z kolei obraz nerki prawej nasuwał podejrzenie drobnego złogu. Proksymalny odcinek lewego moczowodu poszerzony do $21 \mathrm{~mm}$, w dystalnej $1 / 3$ części lewego moczowodu widoczny złóg $6 \mathrm{~mm}$. Chorego konsultowano urologicznie - zalecono podjęcie próby odbarczenia nerki lewej. Przy przyjęciu do Kliniki Endokrynologii pacjent w stanie ogólnym bardzo ciężkim, przytomny, lecz bez możliwości nawiązania logicznego kontaktu, co uniemożliwiło zebranie wywiadu. Według relacji żony pacjenta kilka dni wcześniej pojawiły się "chlustające" wymioty. Stan pacjenta według skali Glasgow został oceniony na 8-9/15 punktów (otwieranie oczu 2pkt; reakcja słowna 2-3 pkt, reakcja ruchowa $4 \mathrm{pkt}$ ). Dokonano oceny parametrów życiowych (tabela 5). Glikemia z krwi włośniczkowej - $98 \mathrm{mg} \%$. W wykonanym TK głowy nie stwierdzono cech krwawienia śródczaszkowego. Obserwowano poszerzone zarysy przysadki mózgowej oraz tkanek $\mathrm{w}$ okolicy lewej zatoki jamistej $\mathrm{z}$ modelowaniem $\mathrm{i}$ ścieńczeniem ściany zatoki klinowej, zlewające się częściowo obszary niedokrwiennomalacyjne w okolicach ciemieniowych, czołowej prawej, nieco mniejsze w okolicach skroniowych, czołowej lewej i okolicach potylicznych. Następnego dnia Pacjent po wyrównaniu hipoglikemii został przekazany do Kliniki Urologii, gdzie wykonano skuteczny zabieg usunięcia kamienia z moczowodu, po czym ponownie przekazano pacjenta do Kliniki Endokrynologii.

Podczas drugiego pobytu w Klinice Endokrynologii pacjent pozostawał w stanie stabilnym. Podczas przebywania chorego na oddziale w badaniu fizykalnym uwagę zwracało opadnięcie powieki oka lewego, sugerujące porażenie n. III. Pilnie wykonano badanie TK głowy (rycina 1) w którym uwidoczniono poszerzone zarysy przysadki mózgowej oraz tkanek w okolicy lewej zatoki jamistej z modelowaniem i ścieńczeniem ściany zatoki klinowej - w porównaniu z badaniem poprzednim przysadka o obniżonej densyjności, zarysy przysadki wydawały się nieco większe niż poprzednio, zwłaszcza od strony zatoki jamistej. W wykonanym badaniu nie stwierdzono cech krwawienia śródczaszkowego. Ze względu na obraz kliniczny wysunięto podejrzenie udaru przysadki, zlecono natychmiastową ocenę osi adrenokortykotropowej i tyreotropowej. W wynikach obserwowano obniżone stężenie hormonów przedniego płata przysadki (tabela 6) oraz kortyzolu. Rozpoznano niedoczynność przysadki. Natychmiast podano $100 \mathrm{mg}$ hydrokortyzonu, następnie rozpoczęto przeciwobrzękowo-substytucyjną dożylną terapię deksametazonem. Kolejnego dnia dołączono preparat L-tyroksyny. W wykonanych badaniach dodatkowych wykazano pełną niedoczynność przysadki w zakresie wszystkich osi (adreno-, tyreo-, somato- i gonadotropowej). Podczas pobytu nie obserwowano poliurii, otrzymano prawidłowe ciężary właściwe moczu, co wykluczyło rozpoznanie moczówki prostej. W wywiadzie brak 
informacji o guzie przysadki, który mógłby ulec udarowi. Celem oceny układu podwzgórzowo-przysadkowego zlecono wykonanie badania rezonansu magnetycznego (MR). W rutynowym teście antygenowym COVID-19 wykonywanym przed skierowaniem Pacjenta do Poradni Diagnostyki Obrazowej uzyskano wynik dodatni. Chory został przeniesiony na Oddział Izolacyjny z zaleceniem dokończenia diagnostyki endokrynologicznej po ustąpieniu fazy zakaźnej COVID-19. W związku z niedoczynnością przysadki, wymagał stałej terapii substytucyjnej glikokortykosteroidami i L-tyroksyną.

Po zakończonym leczeniu na Oddziale Obserwacyjno-Zakaźnym, pacjent został ponownie przyjęty do Kliniki Endokrynologii w stanie ogólnym średnim, wydolny krążeniowo i oddechowo. Pacjent w logicznym kontakcie, nie zgłaszał dolegliwości bólowych, negował duszność, bóle głowy. Objawy oponowe były ujemne. W trakcie aktualnej hospitalizacji na podstawie całości obrazu klinicznego oraz dostępnych wyników badań laboratoryjnych potwierdzono niedoczynność w zakresie wszystkich osi tropowych przysadki, kontynuowano substytucję lewotyroksyną oraz hydrokortyzonem. Wyniki wykonanego badania MR (rycina 2, 3) przemawiają za świeżymi zmianami pokrwotocznymi w obrębie przysadki mózgowej, najprawdopodobniej na tle makrogruczolaka. Badanie uwidoczniło niejednorodną, asymetrycznie powiększoną $(\mathrm{L}>\mathrm{P})$ przysadkę, uwypuklającą się do zatoki klinowej oraz zatoki jamistej po stronie lewej, natomiast ku górze sięgającej poziomu skrzyżowania wzrokowego.

Pacjent $\mathrm{z}$ poprawą stanu ogólnego został wypisany do domu $\mathrm{z}$ zaleceniem terapii substytucyjnej hydrokortyzonem i lewotyroksyną.

\begin{tabular}{|l|l|l|l|}
\hline $\begin{array}{l}\text { Glukoza krwi } \\
\text { włośniczkowej }\end{array}$ & $\begin{array}{l}\text { Ciśnienie tętnicze } \\
\text { krwi }\end{array}$ & Tętno & Saturacja \\
\hline $27 \mathrm{mg} \%$ & $90 / 60 \mathrm{mmHg}$ & $87 / \mathrm{min}$ & $85 \%$ \\
\hline
\end{tabular}

Tabela 1. Podstawowe parametry życiowe (karetka pogotowia ratunkowego).

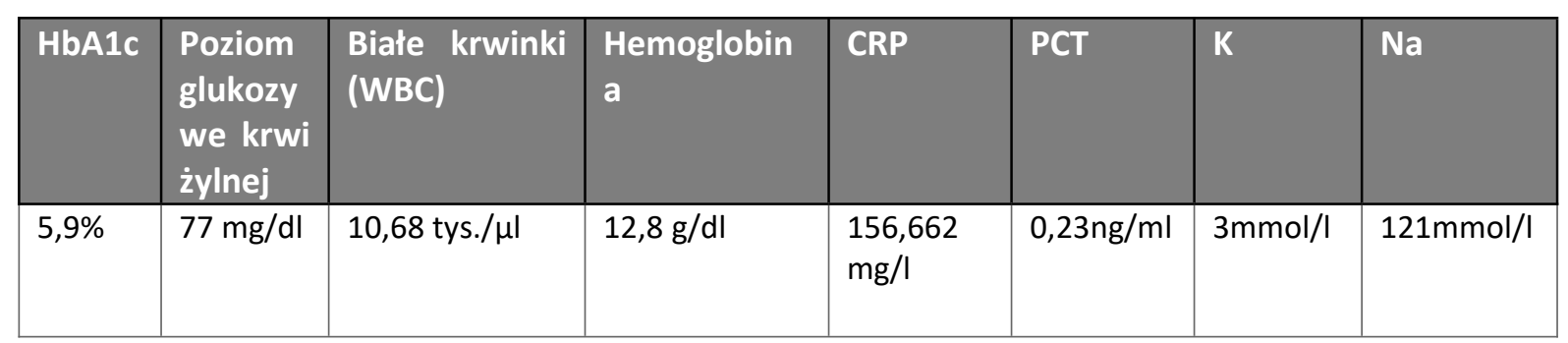

Tabela 2. Wyniki badań wykonanych na Szpitalnym Oddziale Ratunkowym.

\begin{tabular}{|l|l|l|l|l|l|}
\hline kreatynina & eGFR & mocznik & analiza moczu & Tnl & etanol \\
\hline $2,3 \mathrm{mg} / \mathrm{dl}$ & $29,4 \mathrm{ml} / \mathrm{min} / 1,73 \mathrm{~m} 2$ & $45,1 \mathrm{mg} / \mathrm{dl}$ & $\begin{array}{l}\text { cechy infekcji dróg } \\
\text { moczowych, bez } \\
\text { glukozurii } \\
\text { i ketonurii }\end{array}$ & $3 \mathrm{ng} / \mathrm{l}$ & $0,08 \%$ \\
\hline
\end{tabular}

Tabela 3. Wyniki badań wykonanych na Szpitalnym Oddziale Ratunkowym. 


\begin{tabular}{|l|l|l|l|}
\hline \multicolumn{2}{|l|}{ Gazometria krwi tętniczej } \\
\hline $\mathrm{pH}$ & $\mathrm{pCO} 2$ & $\mathrm{pO} 2$ & HCO3- \\
\hline 7,42 & $45,4 \mathrm{mmHg}$ & $99,4 \mathrm{mmHg}$ & $28,4 \mathrm{mmol} / \mathrm{l}$ \\
\hline
\end{tabular}

Tabela 4. Wyniki badań wykonanych na Szpitalnym Oddziale Ratunkowym.

\begin{tabular}{|l|l|l|l|}
\hline temperatura ciała & ciśnienie krwi & tętno & saturacja \\
\hline $36,2^{\circ} \mathrm{C}$ & $86 / 60 \mathrm{mmHg}$ & $84 / \mathrm{min}$ & $97 \%$ \\
\hline
\end{tabular}

Tabela 5. Podstawowe parametry życiowe (Oddział Endokrynologii).

\begin{tabular}{|l|l|l|}
\hline hormon & wartość & zakres referencyjny \\
\hline TSH & $0,034 \mathrm{mlU} / \mathrm{L}$ & $0,550-4,780$ \\
\hline ACTH & $2,60 \mathrm{pg} / \mathrm{ml}$ & $7,20-63,60$ \\
\hline hGH & $<0,030 \mathrm{ng} / \mathrm{ml}$ & $0,030-2,470$ \\
\hline LH & $0,20 \mathrm{mlU} / \mathrm{ml}$ & $3,10-34,60$ \\
\hline PRL & $2,6 \mathrm{ng} / \mathrm{ml}$ & $2,10-17,70$ \\
\hline
\end{tabular}

Tabela 6. Wartości badań hormonalnych.

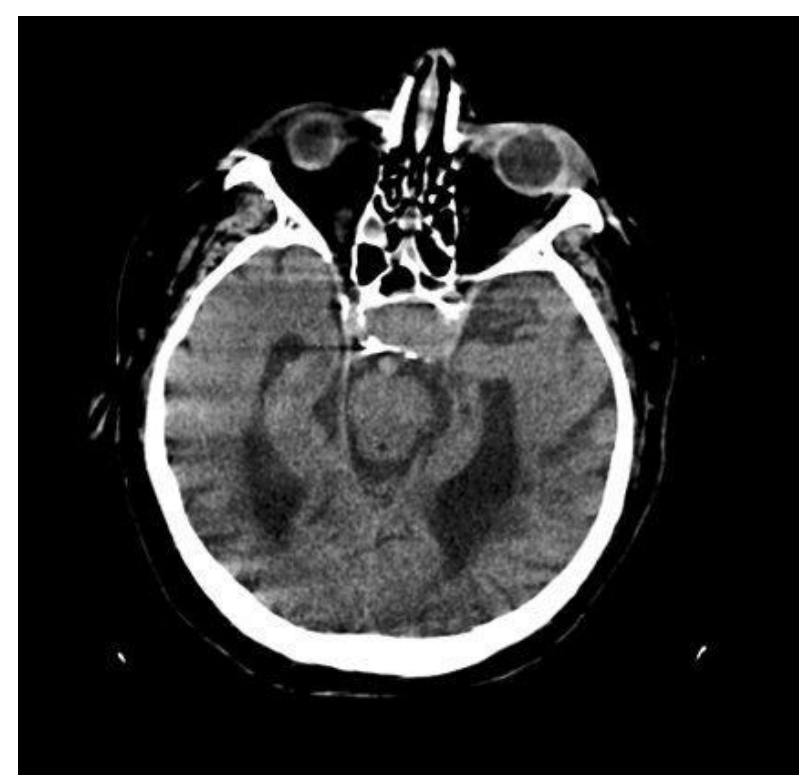

Rycina 1. Obraz tomografii komputerowej.

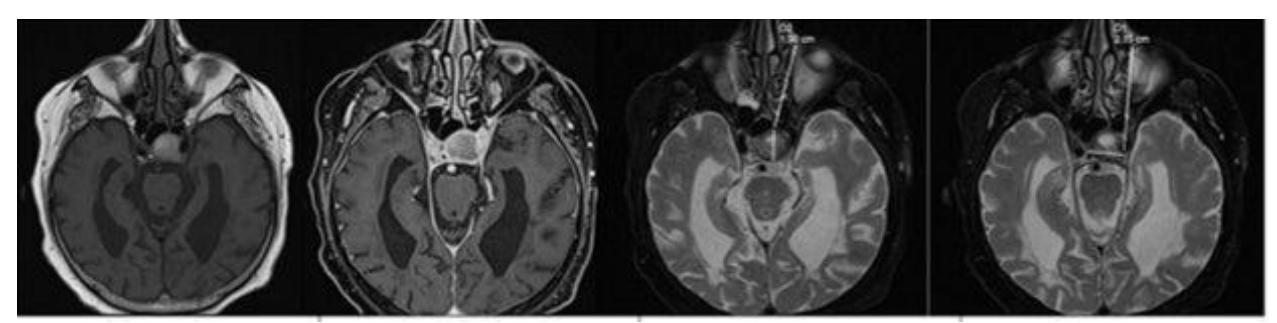

Rycina 2. Obraz rezonansu magnetycznego - projekcja poprzeczna. 


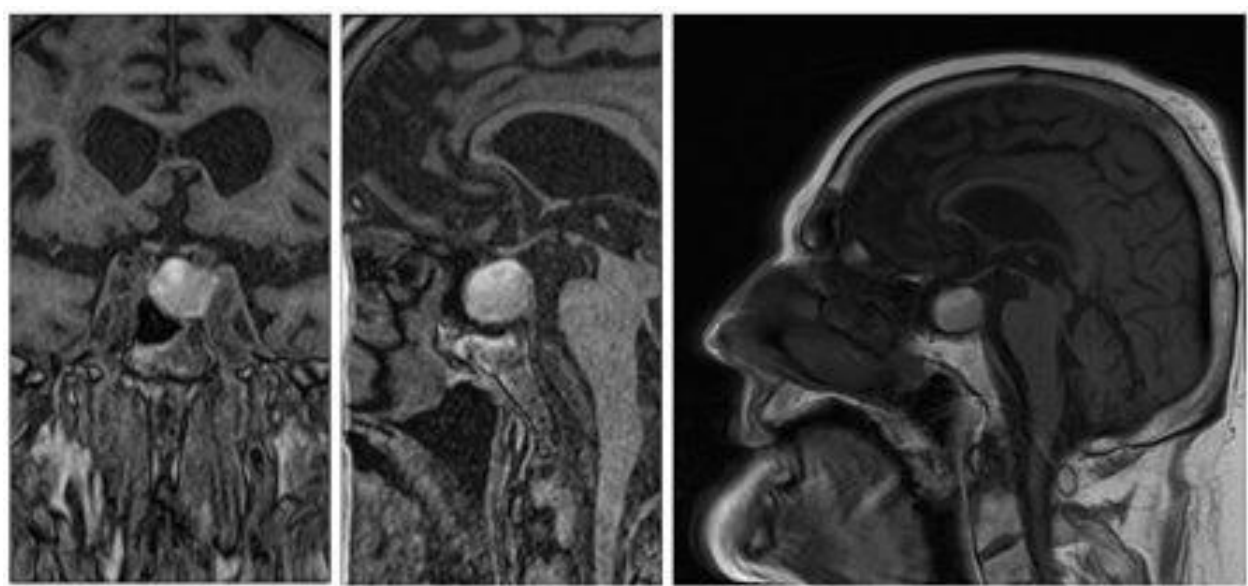

Rycina 3. Obraz rezonansu magnetycznego - projekcja podłużna.

\section{DYSKUSJA}

Następstwa apopleksji przysadki są trudne do przewidzenia. Stan kliniczny chorego może ulec dramatycznemu pogorszeniu na skutek krwotoku podpajęczynówkowego z gruczolaka apoplektycznego lub niedokrwienia mózgu. Udar przysadki może całkowicie zniszczyć gruczolaka podczas gdy w niektórych przypadkach resztki mogą odrastać [1].

Po wystąpieniu apopleksji przysadki, pacjent może doświadczyć udaru niedokrwiennego, choć jest to zdarzenie niezwykle rzadkie. Pomimo małej częstości tego powikłania, należy go brać pod uwagę u chorego z niewyjaśnionym deficytem neurologicznym i szybkim postępem objawów [6]. Udar przysadki poprzez szybki wzrost zawartości wewnątrzsiodłowej prowadzi do nagłego wzrostu ciśnienia $w$ tej okolicy, co jest czynnikiem ryzyka martwicy niedokrwiennej oraz dodatkowo może to ograniczać możliwości przywrócenia funkcji samej przysadki. Wśród mechanizmów niedokrwienia mózgu u pacjentów po przebytej apopleksji przysadki wymienia się niedrożność koła tętniczego Willisa spowodowaną uciskiem powiększającej się masy oraz skurcz tętnic mózgowych, będący następstwem krwotoku podpajęczynówkowego i uwalnianiem substancji wazokonstrykcyjnych z gruczolaka lub podwzgórza. Zawał mózgu wtórny do udaru przysadki wiąże się ze śmiertelnością na poziomie $24 \%$. [12, 13$]$.

Najczęstszym i zarazem najbardziej niebezpiecznym zaburzeniem endokrynologicznym występującym w przebiegu PA jest deficyt ACTH, będący przyczyną wtórnej niedoczynności kory nadnerczy, objawiającej się niedociśnieniem (przy braku kortyzolu, naczynia stają się niewrażliwe na katecholaminy) oraz hiponatremią i hipoglikemią [1, 14]. Mniej powszechne niedobory hormonów mogą obejmować tyreotropinę i gonadotropinę. Natomiast poziom prolaktyny może być zwiększony $\mathrm{z}$ powodu istniejącego prolactinoma lub przerwania hamowania przez dopaminę na skutek ucisku na lejek. Rzadko natomiast występuje dysfunkcja tylnego płata przysadki. Jedynie 5\% pacjentów ma objawy moczówki prostej [15]. Szybkie i prawidłowe rozpoznanie udaru przysadki ma istotny wpływ na dalsze rokowanie pacjenta. Diagnostyka różnicowa obejmuje między innymi: krwotok podpajęczynówkowy, pęknięcie tętniaka, zapalenie opon mózgowo-rdzeniowych, zapalenie tętnic skroniowych, migrenę, zapalenie nerwu wzrokowego oraz zakrzepicę zatoki jamistej [4]. W kontekście ciąży udar przysadki może być mylony między innymi ze stanem przedrzucawkowym [16].

W wyniku szerokiej diagnostyki różnicowej rozpoznanie może być trudne. Udar przysadki może zostać fałszywie zdiagnozowany, ze względu na objawy sugerujące zapalenie opon mózgowo-rdzeniowych (światłowstręt, nudności, wymioty, gorączka oraz nieraz hiperlimfocytoza płynu mózgowo - rdzeniowego) [1]. W analizie 22 przypadków pacjentów, u których PA naśladował zapalenie opon mózgowo-rdzeniowych (ZOMR) stwierdzono pleocytozę płynu mózgowo-rdzeniowego. Zaobserwowano przewagę neutrofilii (odsetek 
neutrofilii od $73 \%$ do $98 \%$ ). Z kolei liczba leukocytów w $86 \%$ przypadków była mniejsza niż

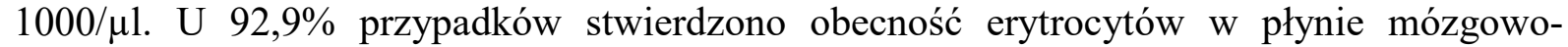
rdzeniowym (PMR), u wszystkich poziom białka był podwyższony. Zmiany te wynikają z wtórnego wycieku krwi i tkanki martwiczej $\mathrm{z}$ przysadki po zawale do przestrzeni podpajęczynówkowej. Pleocytoza zdominowana przez neutrofile jest cechą wspólną dla PA i bakteryjnego zapalenia opon mózgowych. Natomiast liczba leukocytów w PMR poniżej 1000/ $\mu 1$ nie jest typowa dla ZOMR [17]. W celu wykluczenia bakteryjnego zapalenia opon mózgowych wykonuje się posiew PMR. TK jest najczęściej wstępnym badaniem u pacjentów $\mathrm{z}$ nagłym bólem głowy o dużym nasileniu. Badanie pozwala na wykluczenie SAH i w $80 \%$ uwidacznia masę wewnątrzsiodłową. Jednak po kilku dniach gęstość krwi spada i może być trudniejsza do wykrycia [1].

Aktualnie badanie rezonansu magnetycznego wykazuje przewagę nad tomografią komputerową w zakresie wykrywania uszkodzeń przysadki i stanowi metodę $\mathrm{z}$ wyboru $\mathrm{w}$ rozpoznawaniu cech apopleksji przysadki. W obrazie obserwuje się zawał bądź krwotok. W przypadku udaru niedokrwiennego brak jest krwawienia śródsiodłowego. Guz wykazuje niską intensywność sygnału, po podaniu gadolinu nie obserwuje się wzmocnienia, z wyjątkiem obwodowego wzmocnienia torebki guza [4]. Nieraz obserwuje się także zgrubienie błony śluzowej zatoki klinowej, którego przyczyną może być zastój żylny spowodowany wzrostem ciśnienia wewnątrzsiodłowego [18].

Brytyjskie wytyczne dotyczące postępowania z pacjentami z PA wskazują na konieczność pilnego pobrania próbki krwi u chorych z podejrzeniem udaru przysadki w celu sprawdzenia elektrolitów, czynności nerek, wątroby, parametrów krzepnięcia, morfologii krwi, poziomu hormonów przedniego płata przysadki. W celu potwierdzenia rozpoznania należy wykonać badanie rezonansu magnetycznego. W sytuacji, gdy jest to niemożliwe należy wykonać TK [19].

U około dwóch trzecich pacjentów z udarem przysadki występuje ostra wtórna niedoczynność kory nadnerczy, będąca główną przyczyną śmiertelności związaną z tym schorzeniem. W związku z tym, konieczna jest szybka podaż kortykosteroidów. Podaje się hydrokortyzon w dawce 100-200 mg w dożylnym bolusie, a następnie 2-4 mg na godzinę w ciągłym wlewie dożylnym lub 50 - 100 mg co 6 godzin we wstrzyknięciu domięśniowym. Po ustąpieniu stanu ostrego dawkę hydrokortyzonu powinno się zmniejszyć do standardowej dawki podtrzymującej (20-30 mg/dobę) [19].

Postępowanie w przypadku udaru przysadki jest nadal przedmiotem dyskusji. Istnieje wiele kontrowersji dotyczących roli i czasu odbarczania neurochirurgicznego $\mathrm{w}$ postępowaniu $\mathrm{u}$ pacjentów. Decyzja o wykonaniu interwencji chirurgicznej jest trudna ze względu na brak jednoznacznych kryteriów, które uzasadniałyby jej podjęcie. Ogólnie przyjmuje się, że pacjenci niestabilni klinicznie i neurologicznie, z ciężkimi bądź postępującymi zaburzeniami świadomości, ostrości wzroku lub pola widzenia, wymagają pilnej chirurgicznej dekompresji $[2,21]$. Wśród powikłań pooperacyjnych najczęściej występuje przemijająca moczówka prosta, może wystąpić niedobór kortyzolu, utrata wzroku, wyciek płynu mózgowordzeniowego oraz zapalenie opon mózgowych [19].

Autorzy jednej z analiz retrospektywnych uważają, że pionowa średnica guza przekraczająca $35 \mathrm{~mm}$ oraz współwystępująca wada wzroku powinny być wskazaniem do leczenia chirurgicznego. Stwierdzono także, że nie ma ostatecznych dowodów na przewagę interwencji chirurgicznej na leczeniem zachowawczym i odwrotnie, a strategia leczenia powinna być dostosowana indywidualnie do każdego pacjenta [20].

Leczenie zachowawcze polegające na podawaniu kortykosteroidów i wspomaganiu równowagi wodno-elektrolitowej obejmuje pacjentów będących w stabilnym stanie klinicznym, w tym z izolowanym porażeniem oczu [2]. Kortykosteroidy podaje się, aby 
zmniejszyć obrzęk nerwu okoruchowego i ocznego oraz w celu zapobieganiu objawom niewydolności kory nadnerczy, spowodowanej upośledzonym wydzielaniem ACTH [3].

Zarówno pacjenci leczeni zachowawczo, jak i operacyjnie wymagają ścisłej kontroli radiologicznej. Zaleca się wykonanie rezonansu magnetycznego 3-6 miesięcy po udarze, a następnie jeden raz w roku przez kolejne 5 lat, a następnie co dwa lata [19].

$\mathrm{W}$ związku $\mathrm{z}$ niedoborami endokrynologicznymi występującymi $\mathrm{w}$ następstwie udaru, $\mathrm{u}$ chorych powinno się ocenić czynność przysadki po 4-8 tygodniach od incydentu niedokrwienia. Pacjenci wymagają również kontroli ostrości i pola widzenia. Corocznie powinno się u nich dokonywać oceny biochemicznej pod kątem T4, TSH, LH, PRL, IGF-1, $\mathrm{GH}$, kortyzolu, testosteronu u mężczyzn oraz estradiolu u kobiet [19].

\section{WNIOSKI}

Klasyczna triada objawów udaru obejmuje silny, nagły ból głowy, ostrą niedoczynność przysadki oraz zaburzenia widzenia. W przypadku stwierdzenia krwotoku w badaniu obrazowym przy współwystępowaniu wymienionych wyżej objawów można postawić rozpoznanie udaru przysadki [14]. Jednak postawienie takowego rozpoznania często wiąże się $\mathrm{z}$ trudnościami. W przedstawionym przypadku diagnostyka była utrudniona poprzez jednoczesną obecność wielu schorzeń. Występujące objawy były nieswoiste i mogły mieć wiele przyczyn. Podejrzewano, że występująca hipoglikemia mogła wynikać z przyjmowanej przez pacjenta pochodnej sulfonylomocznika. Sporym utrudnieniem w procesie diagnostycznym był utrudniony kontakt z chorym, uniemożliwiający zebranie wywiadu.

Opis przypadku zwraca uwagę na złożoność procesu diagnostycznego dotyczącego poszukiwania przyczyn hipotensji oraz hipoglikemii. U każdego pacjenta $\mathrm{z}$ podejrzeniem udaru przysadki należy wykonać dokładne badanie neurologiczne oraz kompleksową analizę laboratoryjną obejmującą hormony przysadki [10].

Optymalne leczenie tej jednostki chorobowej pozostaje nadal kwestią kontrowersyjną. Wynika to z braku randomizowanych badań prospektywnych. Jednak coraz więcej danych przemawia za leczeniem zachowawczym [17], które również w przedstawionym przypadku przyniosło poprawę stanu klinicznego.

\section{BIBLIOGRAFIA}

1. Briet C, Salanave S, Bonneville JF, et al. Pituitary Apoplexy, Endocrine Reviews. 2015;36(6):622-645. https://doi.org/10.1210/er.2015-1042

2. Goyal P, Utz M, Gupta N, et al. Clinical and imaging features of pituitary apoplexy and role of imaging in differentiation of clinical mimics. Quant Imaging Med Surg. 2018;8(2):219-231. https://doi.org/10.21037/qims.2018.03.08

3. Chan JL, Gregory KD, Smithson SS, et al. Pituitary apoplexy associated with acute COVID-19 infection and pregnancy. Pituitary. 2020;23,716-720. https://doi.org/10.1007/s11102-020-01080-w

4. Zieliński G, Witek P, Koziarski A, et al. Spontaneous regression of non-functioning pituitary adenoma due to pituitary apoplexy following anticoagulation treatment - a case report and review of the literature. Endokrynol Pol 2013;64(1): 4-58.

5. Cardoso ER, Peterson EW. Pituitary apoplexy: a review. Neurosurgery. 1984;14(3):363-73. https://doi.org/10.1227/00006123-198403000-00021

6.Nagure PV, Nikam VR, Garud AS. Pituitary Apoplexy Producing Internal Carotid and Basilar Artery Compression: A Rare Case Report. Asian J Neurosurg. 2018;13(4):1264-1268. https://doi.org/10.4103/ajns.AJNS_90_18

7. Marzoughi S, Ganesh A, Qaddoura A, et al. Pearls \& Oy-sters: Isolated oculomotor nerve palsy due to pituitary apoplexy missed on CT scan. Neurology. 2020;94(16):e1774-e1777. https://doi.org/10.1212/WNL.0000000000009298 
8. Ranabir S, Baruah MP. Pituitary apoplexy. Indian J Endocrinol Metab. 2011;15(3):S188S196. https://doi.org/10.4103/2230-8210.84862

9. Sasagawa Y, Aburano H, Ooiso K, et al. Oculomotor nerve palsy in pituitary apoplexy associated with pituitary adenoma: a radiological analysis with fast imaging employing with steady-state acquisition. Acta Neurochir. 2021;163:383-389. https://doi.org/10.1007/s00701020-04632-y

10. Barkhoudarian G, Kelly DF. Pituitary Apoplexy. Neurosurg Clin N Am. 2019;30(4): 457463. https://doi.org/10.1016/j.nec.2019.06.001

11. Klimko A, Capatina C. Pituitary Macroadenoma Presenting as Acromegaly and Subacute Pituitary Apoplexy: Case Report and Literature Review. Cureus. 2020;12(8): e9612. https://doi.org/10.7759/cureus.9612

12. Pasha SA, Ranganthan LN, Setty VK, et al. Acute Ischaemic Stroke as a Manifestation of Pituitary Apoplexy in a Young Lady. J Clin Diagn Res. 2017;11(5):OD03-OD05. https://doi.org/10.7860/JCDR/2017/25046.9782

13. Elarjani T, Chen S, Cajigas I, et al. Pituitary Apoplexy and Cerebral Infarction: Case Report and Literature Review. World Neurosurgery. 2020;141:73-80. https://doi.org/10.1016/j.wneu.2020.05.276

14. Hahner S, Spinnler C, Fassnacht M, et al. High incidence of adrenal crisis in educated patients with chronic adrenal insufficiency: a prospective study. J Clin Endocrinol Metab. 2015;100(2):407-16. https://doi.org/10.1210/jc.2014-3191

15. Ehresman JS, Bettegowda C. Treatment of Oncologic Emergencies in the Neurocritical Care Unit. In: Nelson S., Nyquist P. (eds) Neurointensive Care Unit. Current Clinical Neurology. Humana, Cham. https://doi.org/10.1007/978-3-030-36548-6_14

16. Jemel M, Kandara H, Riahi M, et al. Gestational pituitary apoplexy: Case series and review of the literature. Journal of Gynecology Obstetrics and Human Reproduction. 2019;48(10):873-881. https://doi.org/10.1016/j.jogoh.2019.05.005

17. Chu C, Perilli GA, Judge C, et al. Pituitary apoplexy mimicking meningoencephalitis: case report and scoping study. Hospital Practice. 2020;48(1):29-34. https://doi.org/10.1080/21548331.2020.1717801

18. Arita K, Kurisu K, Tominaga A et al. Thickening of sphenoid sinus mucosa during the acute stage of pituitary apoplexy. J Neurosurg 2001;95:897-901.

19. Rajasekaran S, Vanderpump M, Baldeweg S, et al. UK guidelines for the management of pituitary apoplexy. Clin Endocrinol (Oxf). 2011;74(1):9-20. https://doi.org10.1111/j.13652265.2010.03913.x

20. Cavalli A, Martin A, Connolly DJA, et al. Pituitary apoplexy: how to define safe boundaries of conservative management? Early and long-term outcomes from a single UK tertiary neurosurgical unit, British Journal of Neurosurgery, 2020; https://doi.org/10.1080/02688697.2020.1812523

21. Murad-Kejbou S, Eggenberger E. Pituitary apoplexy: Evolution, management and prognosis. Curr Opin Ophthalmol. 2009;20:456-61. 